\title{
A Multidimensional Approach of Child Poverty in Indonesia
}

\author{
Nur Widi Astuti*, Firmansyah Firmansyah, Wahyu Widodo \\ Faculty of Economics and Business, Universitas Diponegoro, Semarang, Jawa Tengah - Indonesia
}

\begin{abstract}
This research discuss about child poverty, which is commonly called deprivation. The purpose of this research is to count multidimensional child poverty index as child poverty measuring istrument in 34 provinces of Indonesia, by using composite idex count calculation. Dimensions and indicators used to compose Multidimensional Child Poverty Index in this research are adapting from dimensions and indicators that used in research by Mahadewi and Kodoatie ${ }^{1}$. Besides that, the determination of dimensions and indicator also adjust the availability of data from SUSENAS 2015. The calculation result of Multidimensional Child Poverty shows that 7 provinces pertain to number I priority (high), 9 provinces belong to number II priority (medium-high), 10 provinces include to number III priorities (medium-low), and 8 provinces are number IV priority (low).
\end{abstract}

Keywords: Child Poverty; Multidimensional Child Poverty; SUSENAS

\section{Introduction}

Poverty alleviation in every forms and dimensions are one of the important purposes in Sustainable Development Goals (SDGs). Poverty becomes an important purpose again for SDGs to ensure sustainability achievement of Millennium Development Goals (MDGs). Target that has to be achieved in this main purpose is to end poverty in every form and in everywhere, child is included that is stated in $2^{\text {nd }}$ global goal of SDGs.

Child poverty can detain children to grow and improve according to their potential. Child poverty also often called as deprivation or inability. That inability will bring impact especially for pre-school and elementary age children in finishing their education and future[2]. Gordon, et.al (2003) explain that poverty and deprivation concept are connected each other[3]. Generally deprivation concepts include any condition that not only from income, in other side poverty concept is usually shown by income inadequacy and other sources that make conditions are not reached. One of the unreached aspect is, the predominant school of thought argues that poverty is a major cause of environmental

\footnotetext{
*Corresponding author email: nurwidiastuti.1603@gmail.com
}

degradation and if policy makers want to address environmental issues, then they must first address the poverty problem [10].

Child poverty is a problem that steal people attention because some reason[4]. First, child poverty include global children needs and protection that deserved. Second most of the children do not have control to their economic condition. Third, the unbearability in child time has consequence in the rest of their life. Fourth, some effects of child poverty have spillover effects. Ambariyanto (2013) in his research of "Multidimensional Poverty to Children" also explain about two opinions that make child poverty become an important thing. First, because children are long term invest for society (economical reason). Second, society have responsibility to protect children (social-ethical reason) and children can not determine their economical situation by themselves[5].

Children as an economic object surely have dependency to parents, household or communities where they live. This dependency character surely makes children as a high risk receiver of poverty. Children that grow in poverty circle will tend to become poor in their old time[6]. That thing strengthening Lewis's research that poverty can be transmitted from 
generation to other generation, because children that live in poor family is socialized by same value and purpose[7].

The 2010 Population Census Result shows that Indonesian population is 82 millions people or at least 34,4 percents is under 18 years old people. This fact shows that investing in children is same as investing into half of total Indonesia people. Meanwhile, all the facts that is gathered based in 2014 UNICEF Year Report, 1 of 25 children died before 5 years old. The lack of nutritional intake that is given to children especially in growth period can be happened because the lack of income from household. This thing is proved by 2014 UNICEF Year Report, that 1 of 2 children in Indonesia grow family with income less than $\$ 2$ a day.

The other fact that is collected from Indonesia Demographic and health Surveys (IDHS) until the end of 2013 stated that 3 percent of women under 15 years old have been married and listed as child worker. Research that has been done by about "Uneducational Children Global Study Initiative; Study In Indonesia" that is described in Research Seminar About Children Education Policy in Indonesia stated that children with uneducated mother has 20 times higher chance to not have school than children with high educated mother[9]. Besides that, a girl that married in young age has a risk to destroy her welfare and health.

\section{Methodology}

Indonesia Law Number 23 Year 2002 about Children Protection stated that a child is someone that below of 18 (eighteen) years old, including an unborn child. United Nation (UN) in the Children Rights Convention at 20 November 1989, stated children definition as each human that below eighteen years old except based on children applicable law, maturity is achieved sooner. Children as below eighteen years old individual absolutely does not have ability to provide their own basic needs. They still have dependency to parent, household and their community[6].

Children poverty can be measured by many methods. Roelen and Gassmann summarized many approaches from previous researches that is used as child poverty measurement such as (i) child poverty count measures (monetary approach, Corak approach, and Deprivation approach by Bristol), (ii) child poverty index measures (Child Welfare Index in Europe and American Child and Young Welfare Index), and (iii) holistic child poverty approaches (Young Lives Approach and DEV Framework for Child Poverty)[6].

In this research, researcher use Multidimensional Child Poverty Index by adapting composite index calculation by Mahadewi and Kodoatie[1]. The step that required is by calculating single index (Equation 1.1) for calculating as composite index (Equation 1.2). There is no maximum and minimum limit that applied in each indicator, therefore the maximum limit that is used is 100 percents and minimum limit is 0 percent.
Single Index (SI) Province $=\frac{b-\text { Min Value }}{\text { MaxValue }- \text { Min Value }} \times 100$ (1.1)

(b) is proporsion/percentage in each provinces in Indonesia.

Composite Index $(\mathrm{CI})$ Province $=\frac{S I+S I+S I+S I+\cdots+S I}{n} \times 100$

(n) is the amount of the dimension of composite index formers.

After the index amount in each provinces already collected, then the next step is the 34 provinces can be include into value and priority category (Table I). The Multidimensional child poverty indexing scale that is used in this research is adapting Index scale grouping by Mahadewi and Kodoatie[1].

Table 1. Scale Classification Index Multidimensional Poverty Children

\begin{tabular}{|l|l|l|}
\hline Index Scale & Category of Value & Category of Priority \\
\hline$X>80,0$ & High & I Priority \\
\hline $66,0<X<79,9$ & Medium High & II Priority \\
\hline $50,0<X<65,9$ & Medium Low & III Priority \\
\hline$X<50,0$ & Low & IV Priority \\
\hline
\end{tabular}

Source : Mahadewi and Kodoatie, 2012

The multidimensional child poverty calculation in this research is using Survei Ekonomi Nasional (SUSENAS) in 2005. Dimension and indicator using that is chosen is an adaption of research result by Mahadewi and Kodoatie[1] and BPS[8]. Dimensions that used in this research are 6 dimensions, those are residence quality dimension, environment quality dimension, health dimension, information dimension, education dimension, and social dimension. Dimensions and indicator that chosen in this research are explained in the Table II below.

Table 2. Dimension and Indicator Multidimensional Child Poverty

\begin{tabular}{|c|c|c|c|}
\hline No & Dimension & Indicator & Deprivation Definition \\
\hline \multirow{4}{*}{1.} & \multirow{4}{*}{$\begin{array}{l}\text { RESIDENCE } \\
\text { QUALITY }\end{array}$} & $\begin{array}{l}\text { House F loor } \\
\text { Wide Per } \\
\text { Capita }\end{array}$ & $\begin{array}{l}\text { If floor wide divided by amount } \\
\text { of household } \leq 7,2 \text {, }\end{array}$ \\
\hline & & $\begin{array}{l}\text { House Floor } \\
\text { Main Material }\end{array}$ & If house floor still made of soil \\
\hline & & $\begin{array}{l}\text { House Wall } \\
\text { Main Material }\end{array}$ & If house wall sill made of tembok \\
\hline & & $\begin{array}{l}\text { House Roof } \\
\text { Main Material }\end{array}$ & If house roof still made of straw \\
\hline 2. & $\begin{array}{c}\text { ENVIRONMENT } \\
\text { QUALITY }\end{array}$ & $\begin{array}{l}\text { Main Water } \\
\text { Source to } \\
\text { Drink }\end{array}$ & $\begin{array}{l}\text { If water resource for drinking is } \\
\text { unprotected wells, sheltered } \\
\text { springs, unprotected springs, }\end{array}$ \\
\hline
\end{tabular}




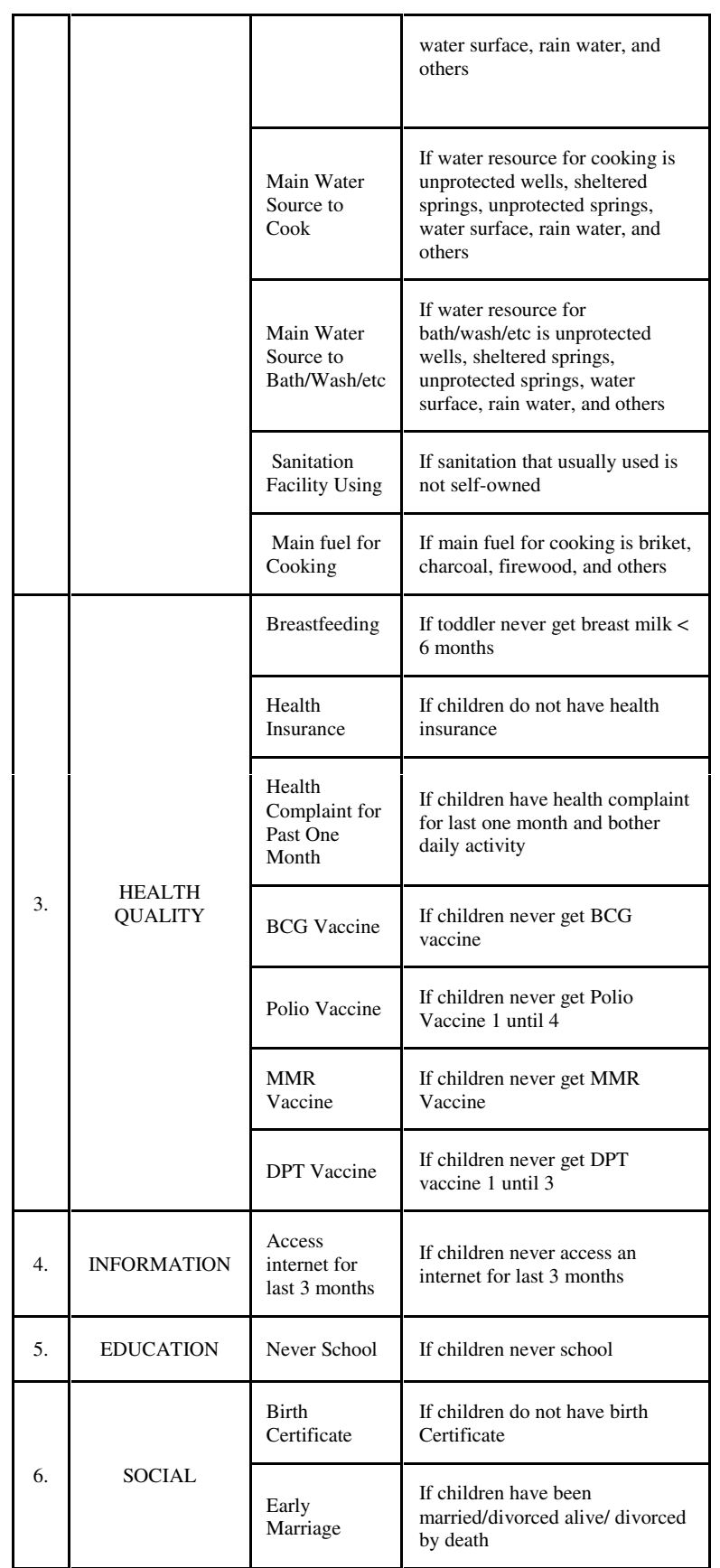

Source : Mahadewi and Kodoatie (2012) and BPS (2017)

\section{Discussion}

Publication by BPS for the last 10 (ten) years shows that the percentage and number of poor people in Indonesia are slowly declining. However, those belonging to poor groups of households have special characteristics that still need concern.

Based on SUSENAS 2015 data mapping, the number of children sampled in this study was 382,749 children and dispersed in 34 provinces in Indonesia. Based on single index calculations, most of children in Indonesia are deprived on the dimensions of environmental quality, housing quality and health.
Meanwhile, children in Papua Province and NTT Province are dominant deprived in 5 (five) dimensions.

Table 3. Multidimensional Child Poverty Index in Indonesia Based on 2015 Province

\begin{tabular}{|c|c|c|c|c|c|}
\hline $\begin{array}{l}\mathbf{N} \\
\mathbf{o}\end{array}$ & Province & $\begin{array}{l}\text { Multidi } \\
\text { mensio } \\
\text { nal } \\
\text { Child } \\
\text { Poverty } \\
\text { Index }\end{array}$ & No & Province & $\begin{array}{l}\text { Multidime } \\
\text { nsional } \\
\text { Child } \\
\text { Poverty } \\
\text { Index }\end{array}$ \\
\hline 1 & Papua & 116,5 & 18 & West Sumatera & 64,8 \\
\hline 2 & $\begin{array}{l}\text { East } \\
\text { Nusa } \\
\text { Tenggara }\end{array}$ & 102,4 & 19 & Gorontalo & 63,7 \\
\hline 3 & $\begin{array}{l}\text { Central } \\
\text { Sulawesi }\end{array}$ & 90,4 & 20 & Lampung & 62,1 \\
\hline 4 & $\begin{array}{l}\text { West } \\
\text { Borneo }\end{array}$ & 89,0 & 21 & West Nusa Tenggara & 62,0 \\
\hline 5 & $\begin{array}{l}\text { West } \\
\text { Sulawesi }\end{array}$ & 87,3 & 22 & Riau & 59,9 \\
\hline 6 & $\begin{array}{l}\text { West } \\
\text { Papua }\end{array}$ & 86,9 & 23 & South Sulawesi & 58,3 \\
\hline 7 & Maluku & 83,2 & 24 & North Sulawesi & 58,2 \\
\hline 8 & $\begin{array}{l}\text { Central } \\
\text { Borneo } \\
\end{array}$ & 77,0 & 25 & Banten & 52,3 \\
\hline 9 & $\begin{array}{l}\text { North } \\
\text { Maluku }\end{array}$ & 75,5 & 26 & Central Java & 50,4 \\
\hline $\begin{array}{l}1 \\
0\end{array}$ & $\begin{array}{l}\text { Southeas } \\
\mathrm{t} \\
\text { Sulawesi }\end{array}$ & 74,0 & 27 & East Java & 50,0 \\
\hline $\begin{array}{l}1 \\
1\end{array}$ & Aceh & 71,4 & 28 & East Borneo & 47,8 \\
\hline $\begin{array}{l}1 \\
2\end{array}$ & $\begin{array}{l}\text { South } \\
\text { Borneo }\end{array}$ & 71,1 & 29 & Riau Islands & 47,6 \\
\hline $\begin{array}{l}1 \\
3\end{array}$ & $\begin{array}{l}\text { North } \\
\text { Sumatera }\end{array}$ & 69,9 & 30 & West Java & 46,6 \\
\hline $\begin{array}{l}1 \\
4\end{array}$ & $\begin{array}{l}\text { Bengkul } \\
\mathrm{u}\end{array}$ & 67,6 & 31 & Bali & 45,8 \\
\hline $\begin{array}{l}1 \\
5\end{array}$ & Jambi & 67,1 & 32 & Bangka Belitung & 44,7 \\
\hline $\begin{array}{l}1 \\
6\end{array}$ & $\begin{array}{l}\text { North } \\
\text { Borneo }\end{array}$ & 66,2 & 33 & DKI Jakarta & 36,7 \\
\hline $\begin{array}{l}1 \\
7\end{array}$ & $\begin{array}{l}\text { South } \\
\text { Sumatera }\end{array}$ & 65,4 & 34 & DI Yogyakarta & 36,5 \\
\hline
\end{tabular}

Source : SUSENAS, 2015

Based on Multidimensional Child Poverty Index counting result in 34 provinces in Indonesia we can get that 7 provinces are categorized in I priority, 9 provinces are categorized in II priority, 10 provinces are categorized in III priority, and 8 provinces are categorized in IV priority (Table III). Province that include in I Priority or have high value index is the province that in Eastern Indonesia most of them. This shows that there is gap of household and children welfare between Eastern Indonesia and other Indonesian region.

\section{Conclusion}

Capturing poverty is less appropriate if only done with monetary approach. Non-monetary approaches should be considered as complementary to poverty measures for more comprehensive identification. The use of non-monetary approaches can provide effective 
poverty alleviation policy, because improvements in one dimension will only have the effect of reducing poverty in small scope and short therm.

Measurement of the Multidimensional Child Poverty Index can be one of the new measures to mapping the deprivation trends in several dimensions, especially in children to prepare for their future. The calculation results of the Multidimensional Child Poverty Index indicates that children living in Eastern Indonesia have a higher potential to be poor.

Uncomplex indicator and dimension, not updated data and ignore the type of territory are the constrains in this research. It should became the recommendation to the next research to develop the indicator and dimension to measure Multidimensional Child Poverty Index.

\section{References}

1. I. A. Mahadewi, and J. M. Kodoatie, Analisis Komponen Pembentuk Indeks Komposit Kemiskinan Anak dan Perlindungan Khusus Anak Serta Pengaruh Tingkat Pendidikan Orang Tua dan Jumlah Penduduk Miskin Terhadap Tingkat Kemiskinan Anak di Provinsi Jawa Tengah, Semarang (2012).
2. J. B. Gunn, and G. J. Duncan, Children and Poverty, The Effect of Poverty on Children, 7, (1997).

3. D. Gordon, et al., Child Poverty in the Developing World, University of Bristol (2003).

4. J. C. Gornick, M. Jantti, Child Poverty in Comparative Perspective: Assessing the Role of Family Structure and Parental Education and Employment, LIS Working Paper Series, No. 570 (2011).

5. Ambariyanto, Kemiskinan Multidimensi Pada Anak, Media Trend, 8, 118-127 (2013).

6. K. Roelen, and F. Gassmann, Measuring Child Poverty \& Well-Being: a literature review, MPRA Paper No. 8981 (2008).

7. M. Sameti, and H.K. Haghighi, Theories of Poverty: A Comparative Analysis, Kuwait Chapter of Arabian Journal of Business and Management Review, 1, (2012).

8. BPS, Analisis Kemiskinan Anak dan Deprivasi Hak-Hak Dasar Anak di Indonesia, (2017).

9. S. Kudus, Inisiatif Global Studi Anak Tidak Sekolah:Studi di Indonesia, Lembaga Penelitian SMERU(2011).

10. A.K. Duraiappah, Poverty and Environmental Degradation: A Review and Analysis of the Nexus, World Development, Vol. 26, No. 12, (1998). 